\title{
Step-by-step design and calculations for water treatment plant units
}

\author{
Shuokr Qarani Aziz ${ }^{1}$, Jwan Sabah Mustafa² \\ ${ }^{1}$ Department of Civil Engineering, College of Engineering, Salahaddin University-Erbil, Iraq \\ ${ }^{2}$ Ministry of Agriculture and Water Resources, General Directorate of Dams and Reservoirs, Erbil, Iraq
}

Correspondence Author: Shuokr Qarani Aziz, Department of Civil Engineering, College of Engineering, Salahaddin University-Erbil, Iraq Email: shuokr.aziz@su.edu.krd

Received date: 20 June 2019, Accepted date: 2 August 2019, Online date: 25 August 2019

Copyright: (c) 2019 Shuokr Qarani Aziz et al., This is an open-access article distributed under the terms of the Creative Commons Attribution License, which permits unrestricted use, distribution, and reproduction in any medium, provided the original author and source are cre dited.

\begin{abstract}
This work presented the design steps and calculation for each unit of the water treatment plant (WTP), due to its crucial role domestically and drinking purpose. It also illustrated and designed the procedures of the water processing units by estimating water demand and designing the unit process. The objectives of this work were to evaluate the water demand for a certain community and to present design steps and calculations for the required units of a WTP. The design of the WTP units was applied to Greater-Zab River water for the selected location in Erbil City-Iraq. The quality and quantity of the Greater-Zab River water at various times were statistically analyzed and presented. The units of the treatment processes involved intake, coagulation, flocculation, sedimentation, adsorption (optional), filtration, disinfection, storage, and pumping. The calculations and detailed drawings of the units were displayed, the average discharge and population used for the WTP design were $60,000 \mathrm{~m}^{3} / \mathrm{day}$ and 200,000 , respectively. Besides, the calculation required some of the parameters to be estimated as field data, which were taken into consideration. The outline results of each unit of the WTP were tabulated. It can be concluded that this work can be used as a source for designing other WTP units. A number of factors such as the age of WTP, maintenance, economical and political situations, technical problems, and water demand had a great impact on the removal efficiency of the WTP units.
\end{abstract}

Keywords: Design, River Water, Treatment Plant, Greater Zab, Water Demand, Quality

\section{INTRODUCTION}

Water treatment processes are applied to surface water sources. Typically, a water treatment plant (WTP) comprises intake, pumping, pre-sedimentation (in some cases), coagulation, flocculation, clarification, adsorption, filtration, disinfection, storage, and pumping to treat water for consumption [1-4]. The designs of a unit or some units for WTPs are available [5-10]. However, forecasting the population size, estimating water demand, and step-by-step designing and drawing WTPs in one published work are currently unavailable. The objectives of the current work were to determine water demand for an individual community, design WTP units on river water step by step, and illustration the required calculations and details of the WTP units.

\section{MATERIALS AND METHODS}

Information about the quality and quantity of Greater-Zab River water were collected [11]. Statistical Package for the Social Sciences (SPSS) was applied for the statistical analysis for both quality and quantity of Greater-Zab River water. Statistical analysis for the obtained data was presented. Water demand was calculated based on the literature [3,10]. Step-by-step design and calculations for the WTP units such as intake, coagulation, flocculation, sedimentation, adsorption (optional), filtration, disinfection, storage, and pumping were given. Results from the design of WTP units were outlined and the removal efficiencies of the WTP units were illustrated as well. Details are shown in the following sections.

\section{Water Demand}

Calculations and designs should be applied to a natural river to obtain accurate and realistic results for a WTP design. Therefore, the current work was applied to the Greater Zab River in Erbil City, Iraq (Figures 1 and 2). The data about the Greater Zab River 
water were obtained from the Ministry of the Municipality and Tourism Directorate of Water in Erbil City, KRG, Iraq [11] The Greater Zab River is one of the main tributaries of the Tigris River, which is one of the large rivers that originated from Turkey and has a length of approximately $392 \mathrm{~km}[12]$

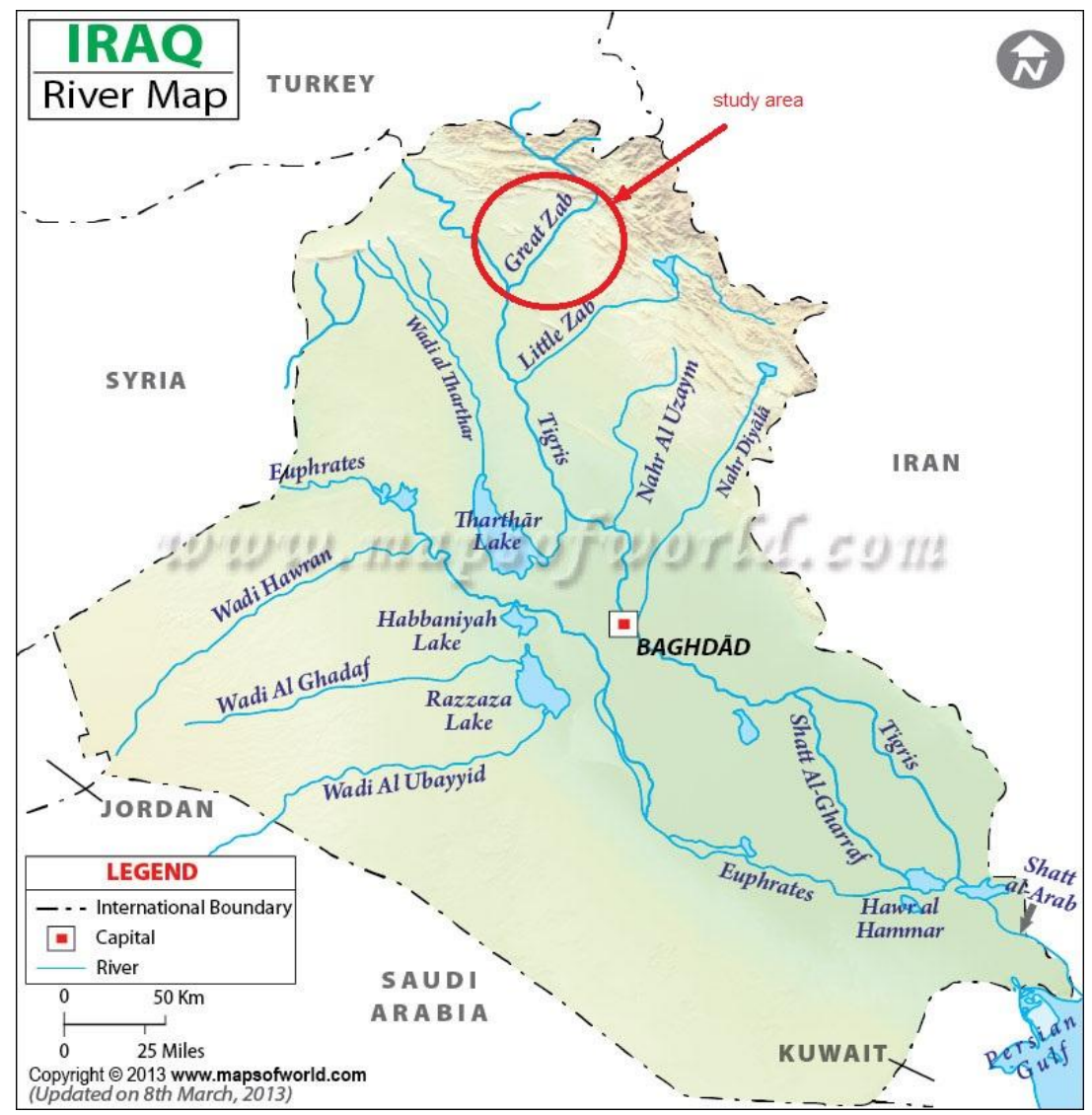

Figure 1. Greater-Zab river on the map

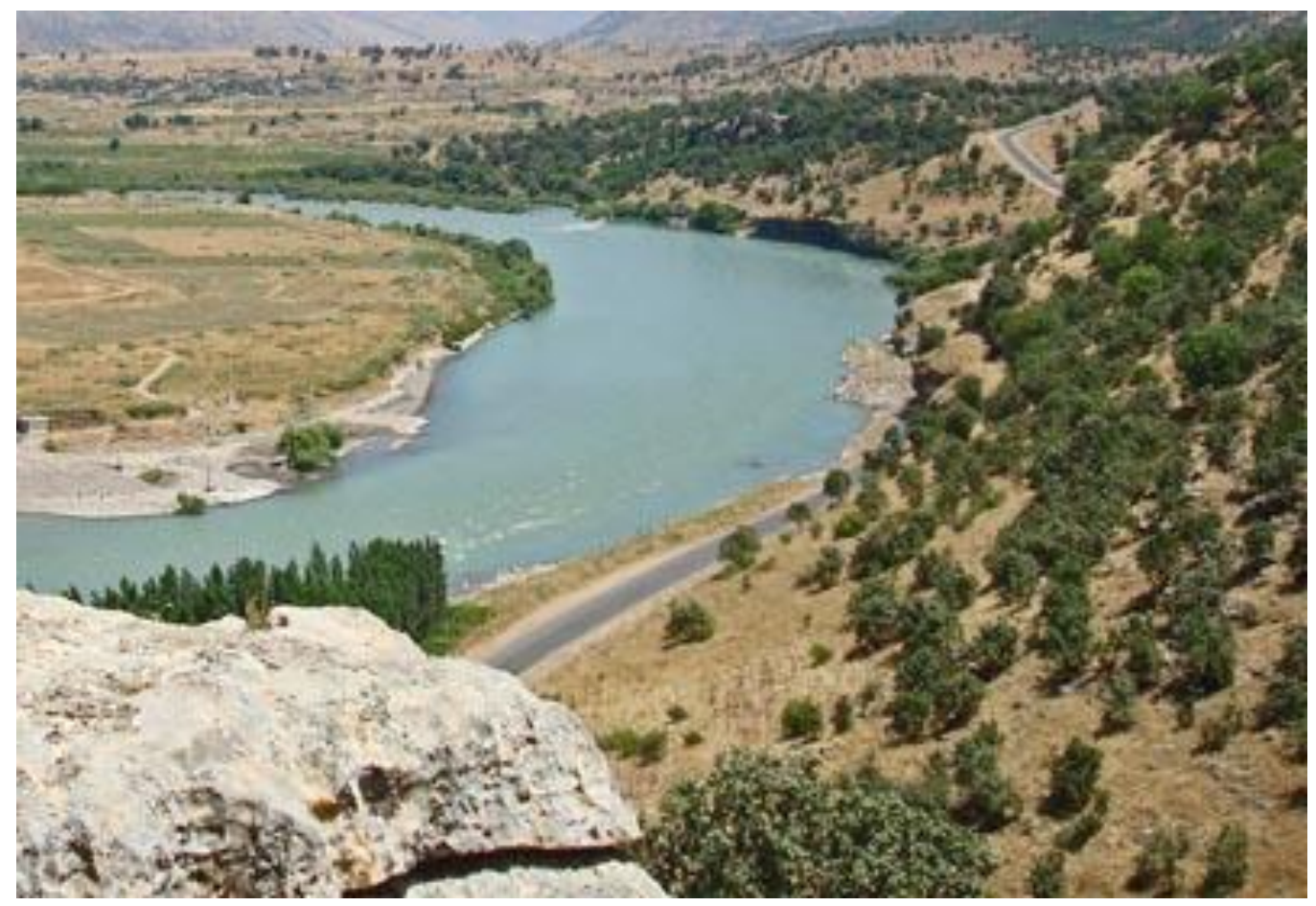

Figure 2. Greater-Zab River

A population of 200,000 and an average water consumption of 300 liter per capita per day (LPCD) were proposed to design an appropriate WTP. The selection of the proposed value of 300 LPCD was based on previous studies $[3,13]$. The minimum and maximum average consumption were suggested as $40 \%$ and $180 \%$, respectively [10]. The discharges can be calculated as follows: 
Average discharge $(\mathrm{Q}$ avg. $)=200,000 \times 300 \mathrm{LPCD}=60,000,000 \mathrm{~L} / \mathrm{day}=60,000 \mathrm{~m}^{3} / \mathrm{day}=0.694 \mathrm{~m}^{3} / \mathrm{s}$

Minimum discharge $(\mathrm{Q} \min )=60,000 \times 0.4=24,000 \mathrm{~m}^{3} / \mathrm{day}=0.278 \mathrm{~m}^{3} / \mathrm{s}$

Maximum discharge $(\mathrm{Q} \max )=60,000 \times 1.8=108,000 \mathrm{~m}^{3} / \mathrm{day}=1.25 \mathrm{~m}^{3} / \mathrm{s}$

\section{Water Quality}

The quality of the Greater Zab River water is summarized in Table 1. Water quality parameters, such as pH, electrical conductivity (EC), total dissolved salts (TDS), chloride $\left(\mathrm{Cl}^{-}\right)$, alkalinity, $\mathrm{Ca}^{++}, \mathrm{Na}^{+}, \mathrm{K}^{+}, \mathrm{Mg}^{++}$, nitrate $\left(\mathrm{NO}_{3}\right)$, and $\mathrm{SO}_{4}$, remained within the allowable limits recommended by WHO standard [11] Turbidity and hardness surpassed the permissible levels of 5 NTU and $200 \mathrm{mg} / \mathrm{L}$ based on WHO standards. Water treatment processes are essential for the Greater Zab River water to adjust all drinking water quality parameters to their acceptable levels to supply potable and safe water to consumers. Table 2 illustrates statistical analysis using SPSS for Greater-Zab River water quality. It can be noticed from Table 2 that the average values of $\mathrm{pH}$, EC, TDS, Cl, Total alkalinity, $\mathrm{Ca}, \mathrm{Na}, \mathrm{K}, \mathrm{Mg}, \mathrm{NO}_{3}$, and $\mathrm{SO}_{4}$ are remaining within the allowable limits mentioned by WHO standards [14]. While the parameters of turbidity and total hardness were surpassed the drinking water quality standards [14]. So, treatment processes for Greater-Zab River water are essential.

Table 1. Quality of Greater-Zab River Water

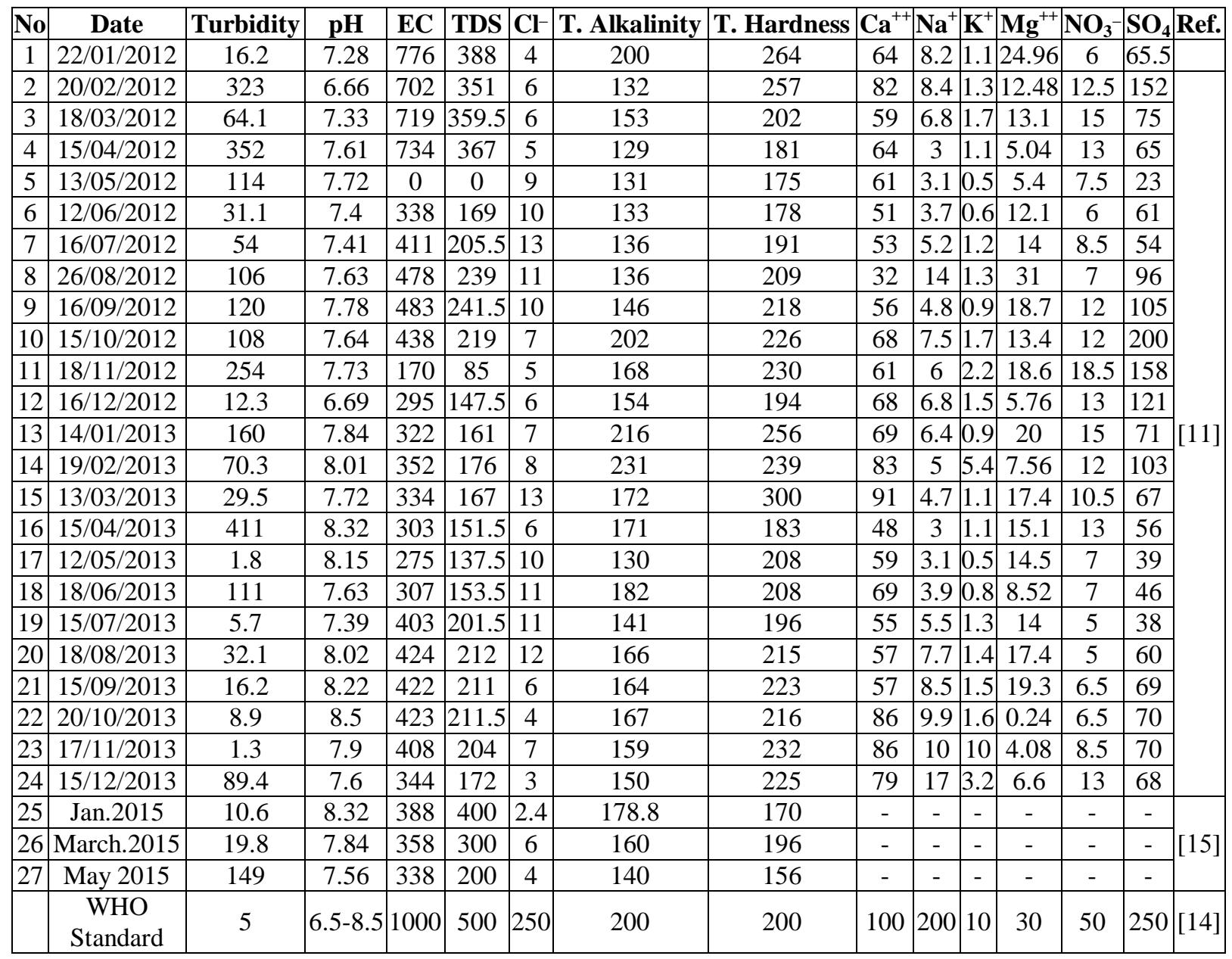

Table 2. Statistical analysis for Greater-Zab River Water quality

\begin{tabular}{|c|c|c|c|c|c|c|c|c|}
\hline \multirow{2}{*}{ Parameters } & \multirow{2}{*}{ N Statistic } & \multirow{2}{*}{ Range } & \multirow{2}{*}{ Minimum } & \multirow{2}{*}{ Maximum } & \multicolumn{2}{|c|}{ Mean } & \multirow{2}{*}{ Std. Deviation } & \multirow{2}{*}{ Variance } \\
\cline { 6 - 9 } & & & & & Statistic & Std. Error & & \\
\hline Turbidity & 27 & 409.70 & 1.30 & 411.00 & 98.9370 & 21.74450 & 112.98772 & 12766.224 \\
\hline pH & 27 & 1.84 & 6.66 & 8.50 & 7.7000 & 0.08358 & 0.43429 & 0.189 \\
\hline E C & 27 & 776.00 & 0.00 & 776.00 & 405.3704 & 32.56382 & 169.20655 & 28630.858 \\
\hline TDS & 27 & 400.00 & 0.00 & 400.00 & 215.9444 & 18.02156 & 93.64277 & 8768.968 \\
\hline Cl & 27 & 10.60 & 2.40 & 13.00 & 7.4963 & 0.59498 & 3.09161 & 9.558 \\
\hline T. Alkalinity & 27 & 102.00 & 129.00 & 231.00 & 161.0296 & 5.24198 & 27.23814 & 741.916 \\
\hline T. Hardness & 27 & 144.00 & 156.00 & 300.00 & 212.8889 & 6.20549 & 32.24466 & 1039.718 \\
\hline Ca & 24 & 59.00 & 32.00 & 91.00 & 64.9167 & 2.87097 & 14.06481 & 197.819 \\
\hline Na & 24 & 14.00 & 3.00 & 17.00 & 6.7583 & 0.70631 & 3.46020 & 11.973 \\
\hline K & 24 & 9.50 & 0.50 & 10.00 & 1.8292 & 0.41092 & 2.01310 & 4.053 \\
\hline
\end{tabular}




\begin{tabular}{|c|c|c|c|c|c|c|c|c|}
\hline $\mathrm{Mg}$ & 24 & 30.76 & 0.24 & 31.00 & 13.3017 & 1.45747 & 7.14013 & 50.982 \\
\hline $\mathrm{NO}_{3}$ & 24 & 13.50 & 5.00 & 18.50 & 10.0000 & 0.76258 & 3.73584 & 13.957 \\
\hline $\mathrm{SO}_{4}$ & 24 & 177.00 & 23.00 & 200.00 & 80.5208 & 8.49027 & 41.59366 & 1730.032 \\
\hline
\end{tabular}

\section{Water Quantity}

The quantity of the Greater-Zab River water is indicated in Table 3. Statistical analysis for Greater-Zab River Water quantity is shown in Table 4. The minimum value of Greater-Zab River water flow was $57 \mathrm{~m}^{3} / \mathrm{s}$ which was reported in September 2001 . Whilst, the maximum flow of $1182 \mathrm{~m}^{3} / \mathrm{s}$ was reported in February 2006. The minimum discharge of the Greater-Zab River is greater than the maximum water demand of $1.25 \mathrm{~m}^{3} / \mathrm{s}$ (Section 3).

Table 3. Quantity of Greater-Zab River water [11]

\begin{tabular}{|c|c|c|c|c|c|c|c|c|c|c|c|c|}
\hline & \multicolumn{10}{|c|}{ Average Discharge (m) $\mathbf{3}$ ) } \\
\hline & Jan. & Feb. & Mar. & Apr. & May & Jun. & Jul. & Aug. & Sept. & Oct. & Nov. & Dec. \\
\hline $\mathbf{2 0 0 1}$ & *N.R & N.R & N.R & N.R & N.R & N.R & N.R & N.R & 57 & 59 & 70 & 309 \\
\hline $\mathbf{2 0 0 2}$ & 223 & 222 & 394 & 1047 & 859 & 500 & 294 & 106 & 87 & 85 & 87 & 259 \\
\hline $\mathbf{2 0 0 3}$ & 242 & 352 & N.R & N.R & N.R & 380 & 193 & N.R & N.R & N.R & N.R & 121 \\
\hline $\mathbf{2 0 0 4}$ & 392 & 401 & 826 & 658 & 674 & 666 & 340 & 114 & 74 & 72 & 80 & 171 \\
\hline $\mathbf{2 0 0 5}$ & 481 & 767 & 1033 & 842 & 644 & 560 & 327 & 108 & 72 & 73 & 80 & 127 \\
\hline $\mathbf{2 0 0 6}$ & 366 & 1182 & 987 & 933 & 733 & 587 & 302 & 155 & 140 & 152 & 262 & 191 \\
\hline $\mathbf{2 0 0 7}$ & 335 & 756 & 742 & 728 & 708 & 445 & 240 & 124 & 100 & 95 & 101 & 119 \\
\hline $\mathbf{2 0 0 8}$ & 98 & 157 & 343 & 324 & 235 & 153 & 89 & 67 & 58 & 75 & 77 & 85 \\
\hline $\mathbf{2 0 0 9}$ & 104 & 132 & 384 & 433 & 486 & 275 & 141 & 84 & 74 & 71 & 174 & 194 \\
\hline $\mathbf{2 0 1 0}$ & 304 & 334 & 439 & 471 & 503 & 317 & 178 & 124 & 102 & 80 & 72 & 75 \\
\hline $\mathbf{2 0 1 1}$ & 90 & 203 & 324 & 613 & 622 & 391 & 227 & 143 & 120 & 117 & 124 & 120 \\
\hline $\mathbf{2 0 1 2}$ & 142 & 206 & 282 & 563 & 513 & 248 & 155 & 119 & 106 & 111 & 140 & 144 \\
\hline $\mathbf{2 0 1 3}$ & 398 & 505 & 540 & 581 & 535 & 402 & 368 & 210 & 185 & 177 & 190 & 225 \\
\hline $\mathbf{2 0 1 4}$ & 242 & 250 & 412 & 393 & 338 & 239 & 182 & 154 & 138 & 202 & 233 & 265 \\
\hline $\mathbf{2 0 1 5}$ & 247 & 253 & 305 & 435 & 407 & 260 & 181 & 149 & 140 & 166 & 211 & 197 \\
\hline $\mathbf{2 0 1 6}$ & 408 & 341 & 535 & 582 & 498 & 318 & 202 & 151 & 135 & 129 & 138 & 178 \\
\hline $\mathbf{2 0 1 7}$ & 164 & 176 & 325 & 578 & 483 & N.R & N.R & N.R & N.R & N.R & N.R & N.R \\
\hline
\end{tabular}

*N.R. means non recorded data

Table 4. Statistical analysis for Greater-Zab River Water quantity $\left(\mathrm{m}^{3} / \mathrm{s}\right)$

\begin{tabular}{|c|c|c|c|c|c|c|c|c|}
\hline & \multirow{2}{*}{ N Statistic } & \multirow{2}{*}{ Range } & \multirow{2}{*}{ Minimum } & \multirow{2}{*}{ Maximum } & \multicolumn{2}{|c|}{ Mean } & \multirow{2}{*}{ Std. Deviation } & \multirow{2}{*}{ Variance } \\
\cline { 6 - 8 } & & & & & Statistic & Std. Error & & \\
\hline January & 16 & 391 & 90 & 481 & 264.7500 & 30.9880 & 123.9500 & 15363.667 \\
\hline February & 16 & 1050 & 132 & 1182 & 389.8125 & 71.46510 & 285.86039 & 81716.163 \\
\hline March & 15 & 751 & 282 & 1033 & 524.7333 & 65.01659 & 251.80817 & 63407.352 \\
\hline April & 15 & 723 & 324 & 1047 & 612.0667 & 52.56800 & 203.59500 & 41450.924 \\
\hline May & 15 & 624 & 235 & 859 & 549.2000 & 41.57783 & 161.03025 & 25930.743 \\
\hline June & 15 & 513 & 153 & 666 & 382.7333 & 37.68509 & 145.95374 & 21302.495 \\
\hline July & 15 & 279 & 89 & 368 & 227.9333 & 21.02911 & 81.44540 & 6633.352 \\
\hline August & 14 & 143 & 67 & 210 & 129.1429 & 9.42166 & 35.25262 & 1242.747 \\
\hline September & 15 & 128 & 57 & 185 & 105.8667 & 9.49580 & 36.77706 & 1352.552 \\
\hline October & 15 & 143 & 59 & 202 & 110.9333 & 11.58014 & 44.84970 & 2011.495 \\
\hline November & 15 & 192 & 70 & 262 & 135.9333 & 16.51333 & 63.95586 & 4090.352 \\
\hline December & 16 & 234 & 75 & 309 & 173.7500 & 16.72760 & 66.91039 & 4477.000 \\
\hline
\end{tabular}

\section{Units of WTP}

\section{Design of WTP Units}

The common steps of river water treatment are provided in Figure 3, and the processes are illustrated in the following diagram. 


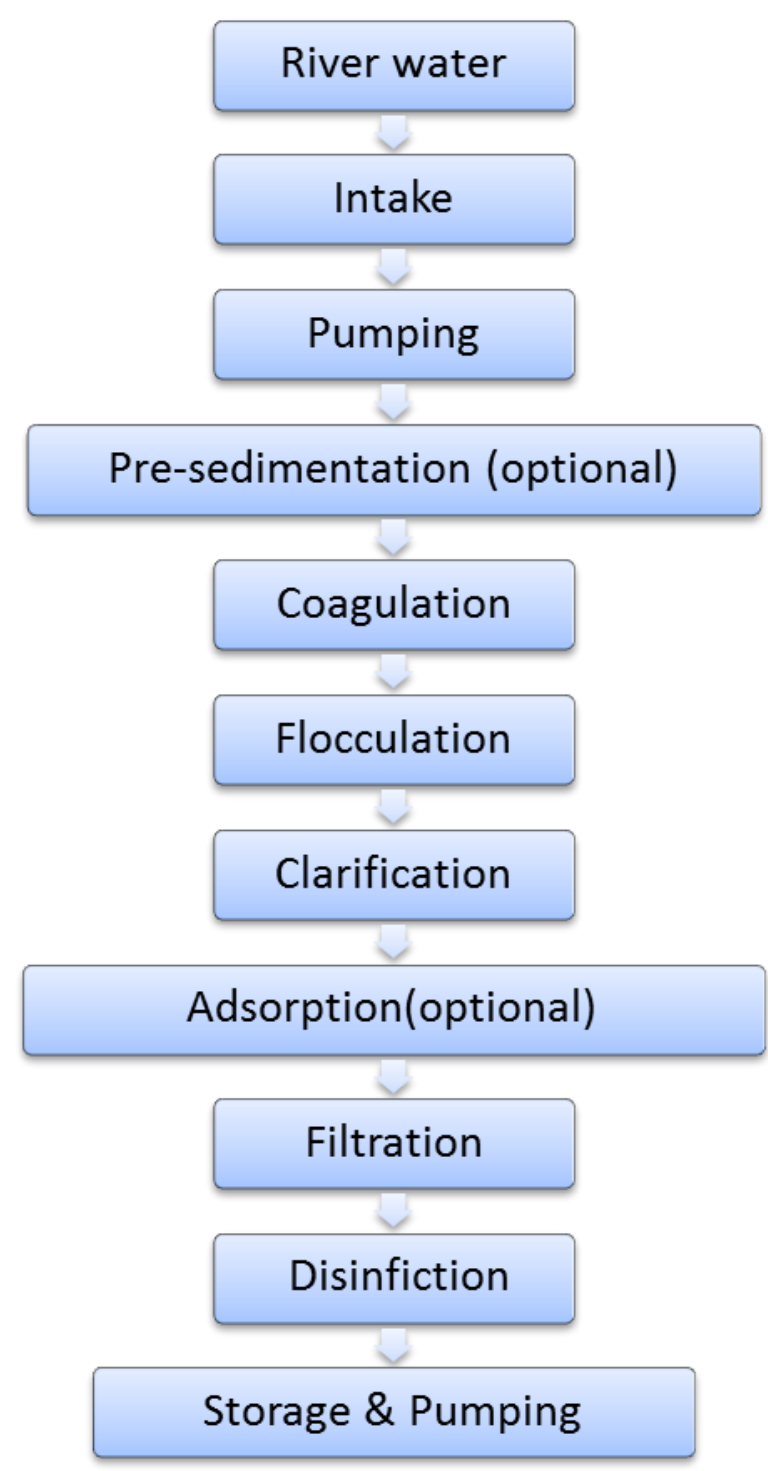

Figure 3. Diagram of Water Treatment processes

\section{Intake}

The basic function of the intake structure is to help safely withdraw water from the water source and to discharge this water into the withdrawal conduit (normally called intake conduit) through which it flows up to a WTP [13,16-17]. The water is diverted through a raw water gravity pipe into the wet well (intake).

The average discharge $\left(Q_{\text {avg. }}\right.$.) used in the design of the intake is described as follows:

$Q_{\text {avg. }}=0.694 \mathrm{~m}^{3} / \mathrm{s}$

when four pipes were used to convey raw water.

$\mathrm{Q}$ per one gravity pipe $=0.694 / 4=0.17 \mathrm{~m}^{3} / \mathrm{s}$.

Velocity inside the gravity pipe $=1 \mathrm{~m} / \mathrm{s}$.

Area $(\mathrm{A})=$ Discharge $(\mathrm{Q}) /$ velocity $(\mathrm{v})$

$$
\begin{aligned}
& =\frac{0.17 \mathrm{~m}^{3} / \mathrm{s}}{1 \mathrm{~m} / \mathrm{s}}=0.17 \mathrm{~m}^{2} \\
& =\frac{\pi \mathrm{D}^{2}}{4} \\
& =0.17 \mathrm{~m}^{2}
\end{aligned}
$$

Diameter $(\mathrm{D})$ of each raw water gravity pipe $=0.47-0.5 \mathrm{~m}$

No. of wells $=4$, circular wells were preferred

Detention time $(\mathrm{t})=20 \mathrm{~min},[13]$

Discharge $(\mathrm{Q})=\frac{\text { Volume }(\mathrm{V})}{\text { Time }(\mathrm{t})}$

$\mathrm{Q}=0.694 \mathrm{~m}^{3} / \mathrm{s}=41.67 \mathrm{~m}^{3} / \mathrm{min}$

$\mathrm{Q}$ for 4 wells $=10.41 \mathrm{~m}^{3} / \mathrm{min}$ 
$\mathrm{V}=\mathrm{Q} \times \mathrm{t}=10.41 \times 20=208.2 \mathrm{~m}^{3}$

The bottom of the well is located at $1.5 \mathrm{~m}$ below of lower water level (LWL) [13]

Effective depth of the intake well $=10 \mathrm{~m}$ [13]

Area of the well $=208.2 / 10=20.82 \mathrm{~m}^{3}$

To find the diameter of the circular well section:

$\mathrm{A}=\frac{\pi}{4} \mathrm{D}^{2}$

$\mathrm{D}=\sqrt{\frac{4 \times 20.82}{\pi}}=5.15 \mathrm{~m}$

The plan of the intakes is shown in Figure 4:

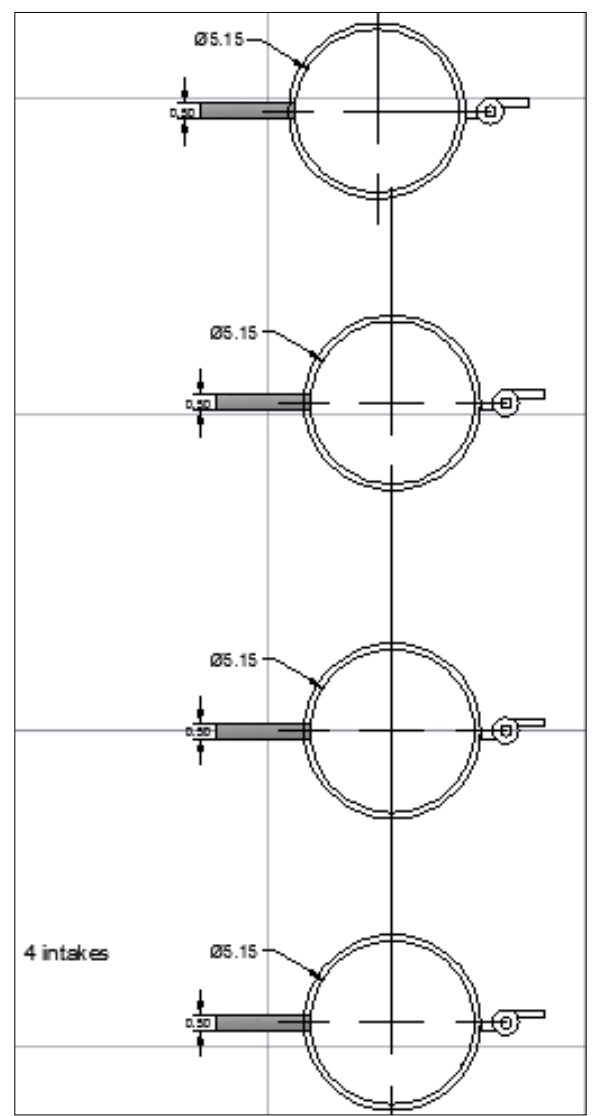

Figure 4. Plan of the intakes

The design of the suction pipe is as follows:

$\mathrm{Q}=0.17 \mathrm{~m}^{3} / \mathrm{s}$

$\mathrm{V}=1.5 \mathrm{~m} / \mathrm{s}$

The cross-sectional area of the suction pipe is $A=Q / v=0.17 / 1.5=0.11 \mathrm{~m}^{2}$.

$\mathrm{D}=\sqrt{\frac{4 \times 0.11}{\pi}}=0.37 \mathrm{~m}($ Use $\mathrm{D}=0.4 \mathrm{~m})$

$\mathrm{Q}$ back washing $=1 / 3 \mathrm{Q}=0.17 / 3=0.06 \mathrm{~m}^{3} / \mathrm{s}$.

Velocity of water in backwashing pipe $=3 \mathrm{~m} / \mathrm{s}[13]$

Cross-sectional area of the pipe $A=Q / v=0.17 / 3=0.06 \mathrm{~m}^{2}$

$\mathrm{D}=\sqrt{\frac{4 \times 0.06}{\pi}}=0.28 \mathrm{~m} \approx 0.3 \mathrm{~m}$

The detail of the intake is presented in Figure 5: 


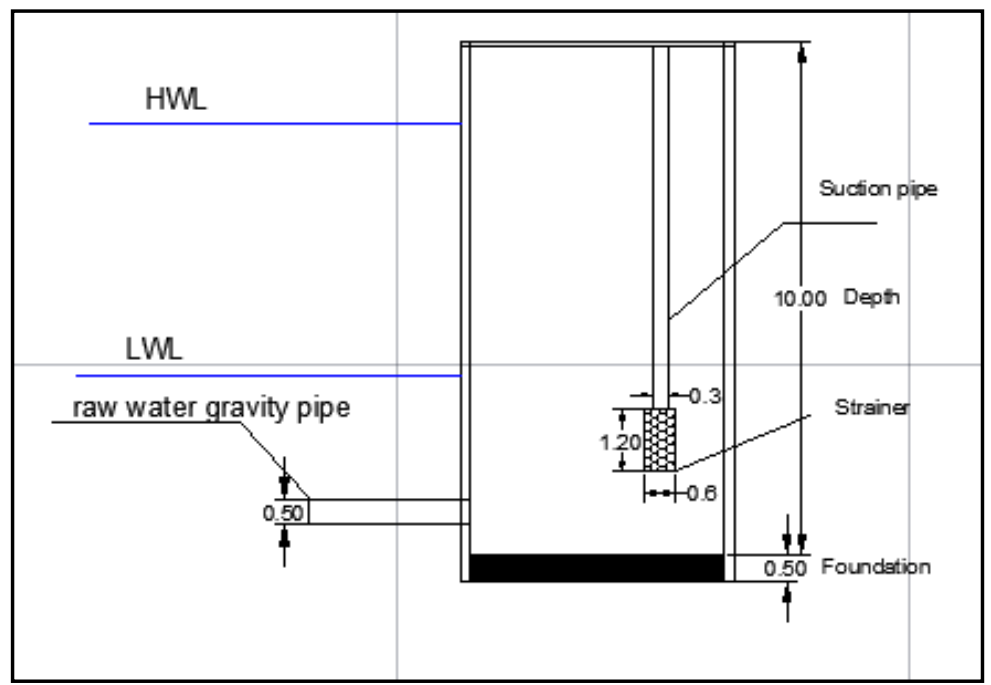

Figure 5. Detail of one of the wet wells

On the basis of the provided data from the directorate of Erbil water of the Greater Zab River, we find that the high-water level (HWL) is $6.3 \mathrm{~m}$, the LWL is $3.4 \mathrm{~m}$, and the groundwater level is 290 m.a.s.l. The following criteria are considered:

Total discharge $(\mathrm{Q})=0.694 \mathrm{~m}^{3} / \mathrm{s}$

To design one strainer:

Total discharge $/ 4=0.17 \mathrm{~m}^{3} / \mathrm{s}$

Velocity through strainer $(\mathrm{v})=0.15 \mathrm{~m} / \mathrm{s}[13,16]$

$\mathrm{A}=\frac{\mathrm{Q}}{\mathrm{V}}=\frac{0.17}{0.15}=1.13 \mathrm{~m}^{2}$

If the area of strainers is $50 \%$ of the total area (Figure 6).

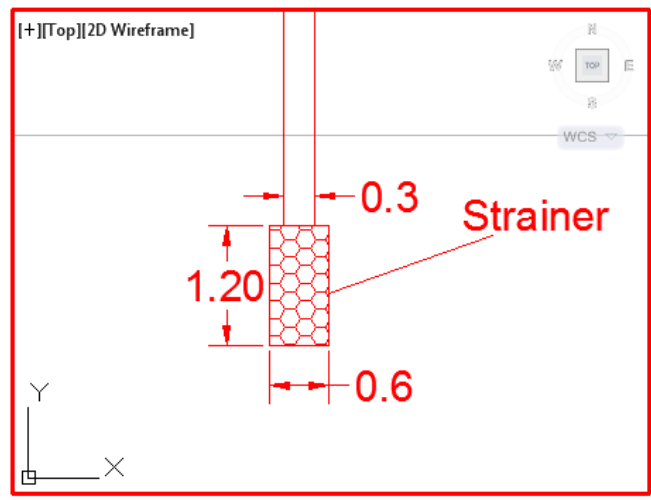

Figure 6. Detail of the strainer

Gross Area $=2 \times$ Area of the strainers (holes)

$$
\begin{aligned}
& =2 \times 1.13 \mathrm{~m}^{2} \\
& =2.26 \mathrm{~m}^{2}
\end{aligned}
$$

Diameter of the hole $=12 \mathrm{~mm},[13,16]$.

Area of one hole $=$ A hole $=\frac{\pi}{4}\left(\frac{12}{1000}\right)^{2}=0.000113 \mathrm{~m}^{2}$

Number of the hole $=\frac{1.13 \mathrm{~m}^{2}}{0.000113 \mathrm{~m}^{2}}=10,000$ hole

To find the strainer diameter $=\frac{\text { Gross Area }}{2 \pi \mathrm{rh}}$

Height of the rectangular shape strainer with closed end $h=1.2 \mathrm{~m}$

Strainer Diameter $(\mathrm{D})=\frac{2.26}{3.14 \times 1.2}=0.6 \mathrm{~m}$

\section{Coagulation}

Coagulation is the process of adding a coagulant to water to destabilize colloidal suspensions, and the steps of the design criteria of the coagulation tank in accordance with previous studies $[1,17]$ are as follows:

$\mathrm{Q}=0.694 \mathrm{~m}^{3} / \mathrm{s}=41.64 \mathrm{~m}^{3} / \mathrm{min}$

using two flash mixers, we determined the discharge for one flash mixer as $\left(41.64 \mathrm{~m}^{3} / \mathrm{min}\right) / 2=20.82 \mathrm{~m}^{3} / \mathrm{min}$.

Use $\mathrm{t}=1 \mathrm{~min}(60 \mathrm{sec}),[13,17-18]$

Volume of flash mixer $(\mathrm{V})=20.82 \mathrm{~m}^{3} / \min \times 1 \mathrm{~min}=20.82 \mathrm{~m}^{3}$ 
Depth of the tank $(\mathrm{d})=3 \mathrm{~m}$

$\mathrm{A}=\mathrm{V} / \mathrm{d}=20.82 \mathrm{~m}^{3} / 3 \mathrm{~m}=6.94 \mathrm{~m}^{2}$

The circular section of the tank was used, and the diameter was obtained using the following equation:

$\mathrm{D}=\sqrt{\frac{4 \times 6.94}{\pi}}=2.97 \mathrm{~m}$, say $3 \mathrm{~m}$.

At $\mathrm{T}=20^{\circ} \mathrm{C}$, dynamic viscosity $\left(\mu=1.0087 \times 10^{-3} \mathrm{~Pa}\right.$. s) was determined in accordance with previously described methods [13]:

For rapid mixing, $\mathrm{G}$ is $>300 / \mathrm{s}$ or more $[17,19]$ :

$\mathrm{G}=1,000 / \mathrm{s}$ is proposed to be used in power calculation [13]

$\mathrm{V}=20.82 \mathrm{~m}^{3}$

Power $=\mathrm{P}=\mathrm{G}^{2} \mu \mathrm{V} \quad$ (3) $[19-20]$

where $\mathrm{G}$ is the mean velocity gradient (/s), $\mathrm{P}$ is the power dissipated (watt), $\mu$ is the dynamic viscosity ( $\mathrm{Pa} / \mathrm{s})$, and $\mathrm{V}$ is the volume of the tank $\left(\mathrm{m}^{3}\right)$.

$\mathrm{P}=(1,000 / \mathrm{s}) \times\left(1.0087 \times 10^{-3} \mathrm{~Pa} / \mathrm{s}\right) \times\left(20.82 \mathrm{~m}^{3}\right)$

$\mathrm{P}=21,001.134$ Watt $\approx 21 \mathrm{~kW}$

To determine the amount of the coagulant (e.g., alum) required per day (kg/day), we used the optimum dosage of alum at $25 \mathrm{mg} / \mathrm{L}$ (normally optimum dosage determined by Jar test), and we supposed that the density of alum was $600 \mathrm{~kg} / \mathrm{m}^{3}$.

$\mathrm{Q}=0.694 \mathrm{~m}^{3} / \mathrm{s} \times 3600 \times 24=59,961.6 \mathrm{~m}^{3} /$ day

Amount of alum $=\frac{25 \mathrm{mg}}{\mathrm{l}} \times \frac{1,000 \mathrm{~L}}{1 \mathrm{~m}^{3}} \times \frac{1 \mathrm{~kg}}{1,000 \mathrm{mg}} \times \frac{5,9961.6 \mathrm{~m}^{3}}{\text { day }}$

Density $=$ mass $/$ volume

$=1,499.04 \approx 1500 \mathrm{~kg} /$ day

$$
=45,000 \mathrm{~kg} / \mathrm{month}
$$

Volume of alum $=$ mass $/$ density

$$
=1,500 \mathrm{~kg} / \text { day } / 600 \mathrm{~kg} / \mathrm{m}^{3}=2.5 \mathrm{~m}^{3} / \text { day }=75 \mathrm{~m}^{3} / \text { month }
$$

The details of one flash mixer are depicted in Figure 7:

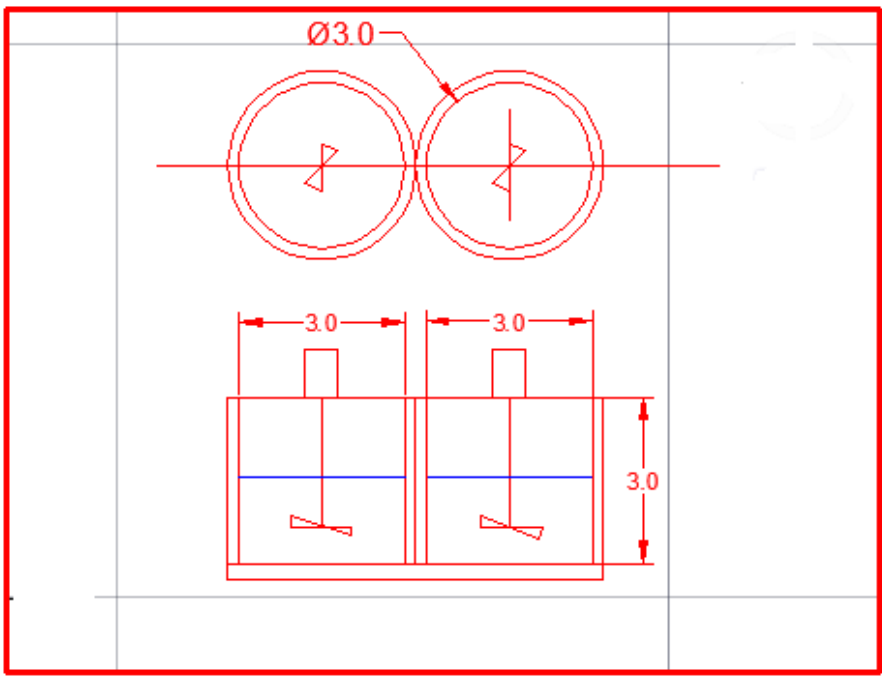

Figure 7. Details of coagulation tanks

\section{Flocculation}

Flocculation is the process of slow mixing that can be achieved in a basin, which is known as a flocculator. It is an essential operation designed to agitate force in fluid and coagulation. The design criteria of the flocculation tank are based on previous studies [2, 19]:

$\mathrm{Q}=41.64 \mathrm{~m}^{3} / \mathrm{min}$

$\mathrm{t}=30 \mathrm{~min}$

$\mathrm{V}=41.64 \mathrm{~m}^{3} / \mathrm{min} \times 30 \mathrm{~min}=1,249.2 \mathrm{~m}^{3}$.

Using six flocculation tanks (with two parallel tanks) $=1,249.2 / 6=208.2 \mathrm{~m}^{3}$

$\mathrm{d}=4 \mathrm{~m}$

$\mathrm{A}=\mathrm{V} / \mathrm{d}=208.2 / 4=52.05 \mathrm{~m}^{2}$

Then, to find the dimension of one square tank, we use the following:

Area $=$ width $\times$ length

Using $\mathrm{L}=3 \mathrm{~W}$

$\mathrm{A}=\mathrm{W} \times 3 \mathrm{~W}$

$52.05=3 \mathrm{~W}^{2}$

$\mathrm{W}=4.17 \mathrm{~m}$ 
$P=G^{2} \mu \mathrm{V}$

To find out the power of each of the paddle, we apply the following:

For $(\mathrm{G}=60 / \mathrm{s})$ rapid mixing $\mathrm{P}=(60)^{2} \times\left(1.0087 \times 10^{-3}\right) \times(208.2)=756.04 \mathrm{Watt}$

For $(\mathrm{G}=40 / \mathrm{s})$ medium mixing $\mathrm{P}=(40)^{2} \times\left(1.0087 \times 10^{-3}\right) \times(208.2)=336.02$ Watt

For $(\mathrm{G}=20 / \mathrm{s})$ slow mixing $\mathrm{P}=(20)^{2} \times\left(1.0087 \times 10^{-3}\right) \times(208.2)=84$ Watt

The details of both the plan and side views of the flocculation tanks are illustrated in Figure 8:

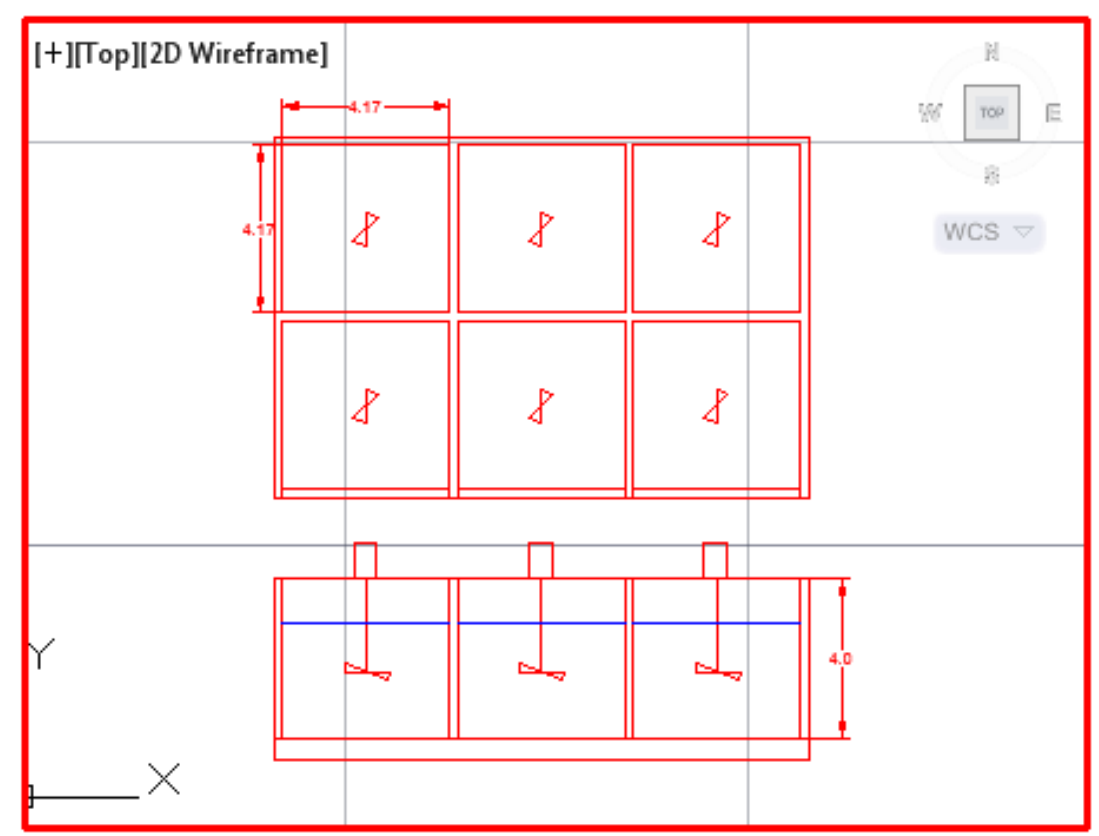

Figure 8. Plan and Side view of the flocculation tanks

\section{Clarification}

Sedimentation, also known as settling or clarification, is the process of removing solid particles by gravity [4,17].

To design a clarification tank, we use the following:

$\mathrm{Q}=0.694 \mathrm{~m}^{3} / \mathrm{s}$

Using four clarification tanks, we used same numbers in Erbil WTP.

For the design of one tank:

$\mathrm{Q}$ per tank $=\mathrm{Q} / 4=0.17 \mathrm{~m}^{3} / \mathrm{s}=10.2 \mathrm{~m}^{3} / \mathrm{min}$

Detention time $(\mathrm{t})=2 \mathrm{~h}=120 \mathrm{~min}$, according to the design criteria described [13]

Volume $=$ discharge $\times$ time

$\mathrm{V}=10.2 \mathrm{~m}^{3} / \mathrm{min} \times 120 \mathrm{~min}$

$\mathrm{V}=1,224 \mathrm{~m}^{3}$

Depth of the clarification $=4 \mathrm{~m}$, [13]

Therefore:

Area $=$ Volume $/$ depth

$\mathrm{A}=1,224 \mathrm{~m}^{3} / 4 \mathrm{~m}$

$\mathrm{A}=306 \mathrm{~m}^{2}$

To find the diameter of the circular sedimentation tank shape, we use the following:

$\mathrm{D}=\sqrt{\frac{4 \times 306}{\pi}}=19.74 \mathrm{~m}, \quad$ Say $20 \mathrm{~m}$

To check the settling velocity [19]

Assuming stock's law is valid:

$\mathrm{Vs}=\frac{\mathrm{g}(\mathrm{Gs}-\mathrm{Gw}) \mathrm{ds}^{2}}{18 \mu}$

where Vs is the terminal settling velocity of the solid particle $(\mathrm{m} / \mathrm{s})$, g is the gravitational acceleration $\left(\mathrm{m} / \mathrm{s}^{2}\right)$, Gs is the specific gravity of particles, $\mathrm{Gw}$ is the specific gravity of water, ds is the diameter of particle (m); and $v$ is the dynamic viscosity of water $\left(\mathrm{m}^{2} / \mathrm{s}\right)$.

Specific gravity of particles $(\mathrm{Gs})=2.6$

Specific gravity of water $(\mathrm{Gw})=1$

Diameter of the particles $(\mathrm{ds})=0.02 \mathrm{~mm}$, [13]

Dynamic viscosity of water at $20^{\circ} \mathrm{C}=1.009 \times 10^{-3} \mathrm{pa} / \mathrm{s}$ 
$\mathrm{Vs}=\frac{9.81(2650-998.207)(0.02 / 1000)^{2}}{18 \times\left(1.002 \times 10^{-3}\right)}=3.59 \times \frac{10^{-4} \mathrm{~m}}{\mathrm{~s}}=0.3594 \mathrm{~mm} / \mathrm{s}$

Reynold's number $(\mathrm{Re})=\frac{\mathrm{V}_{\mathrm{s}} \mathrm{d}_{\mathrm{s}}}{\mathrm{v}}$

$\operatorname{Re}=\frac{\left(3.59 \times 10^{-4}\right) \mathrm{m} / \mathrm{s} \times(0.02 / 1000) \mathrm{m}}{\left(1.004 \times 10^{-6}\right)}$

$\mathrm{Re}=0.0716<1$ (stock's law is applicable).

To design the weir:

$\left(90^{\circ} \mathrm{v}\right.$-notch) shape weir $(50 \mathrm{~mm})$ depth placed $(250 \mathrm{~mm})$ center to center,[13]

Weir loading rate $(\mathrm{WLR})=\mathrm{Q} / \pi \mathrm{D}$

$\mathrm{WLR}=10.2 \mathrm{~m}^{3} / \mathrm{min} /(3.14 \times 28 \mathrm{~m})$

$\mathrm{WLR}=0.116 \mathrm{~m}^{3} / \mathrm{min} / \mathrm{m}$ or $\left(167.06 \mathrm{~m}^{3} / \mathrm{day} / \mathrm{m}\right)$; it is within the allowable range $[4,13,17]$

Q notch $=\frac{\mathrm{Q}}{\frac{1 \mathrm{~m}}{\text { spacing betweein weir }}}=\frac{0.116 \mathrm{~m} 3 / \mathrm{min} \cdot \mathrm{m}}{\frac{1 \mathrm{~m}}{0.250 \mathrm{~m}}}$
$\mathrm{Q}$ notch $=0.029 \mathrm{~m}^{3} / \mathrm{min}=0.00048 \mathrm{~m}^{3} / \mathrm{s}$

$\mathrm{Q}$ notch $=0.312(2 \mathrm{~g})^{0.5} \times \mathrm{h}^{2.5}$

$0.00048=0.312(2 \times 9.81)^{0.5} \times h^{2.5}$

Height of the water above or bottom of the weir $(\mathrm{h}=0.041 \mathrm{~m})$. The details of the clarification are given in Figures 9 and 10 :

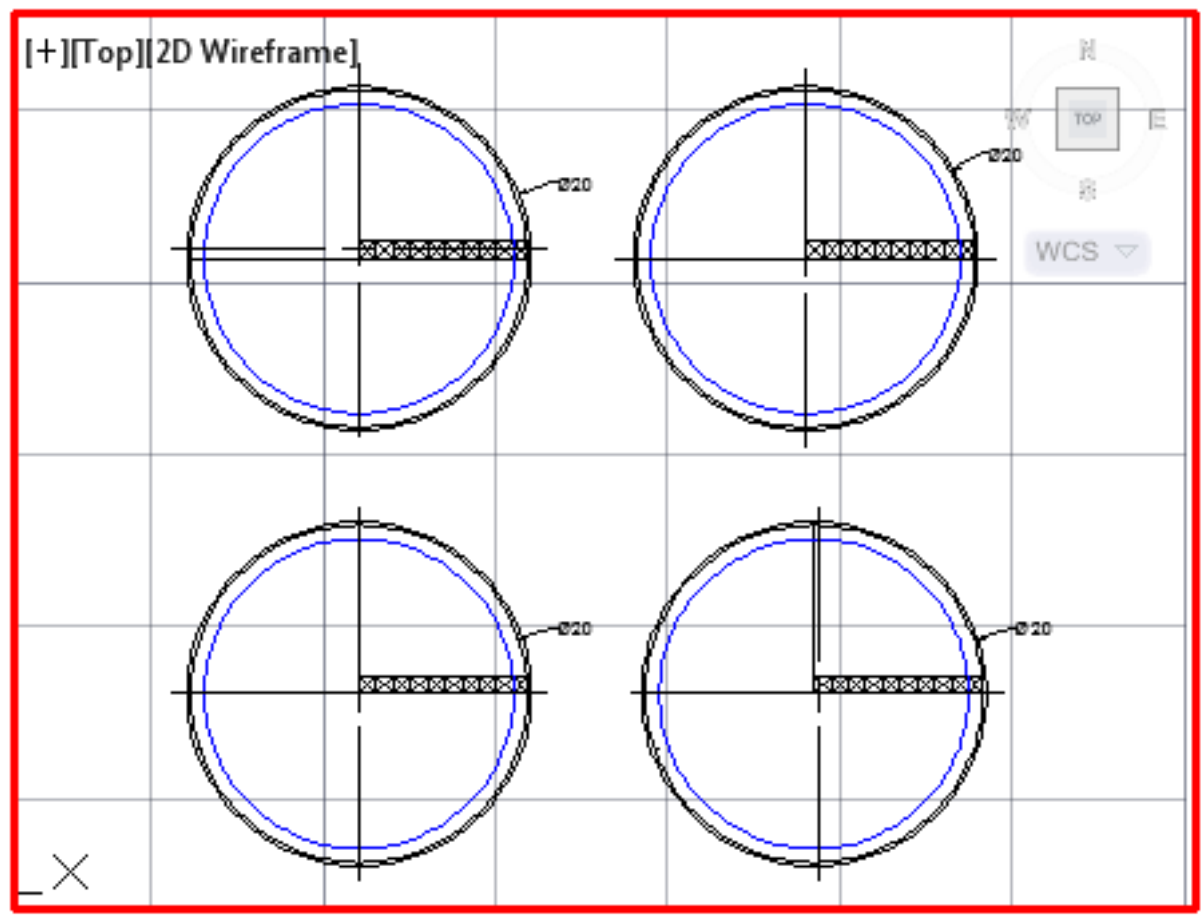

Figure 9. Plan of the clarification

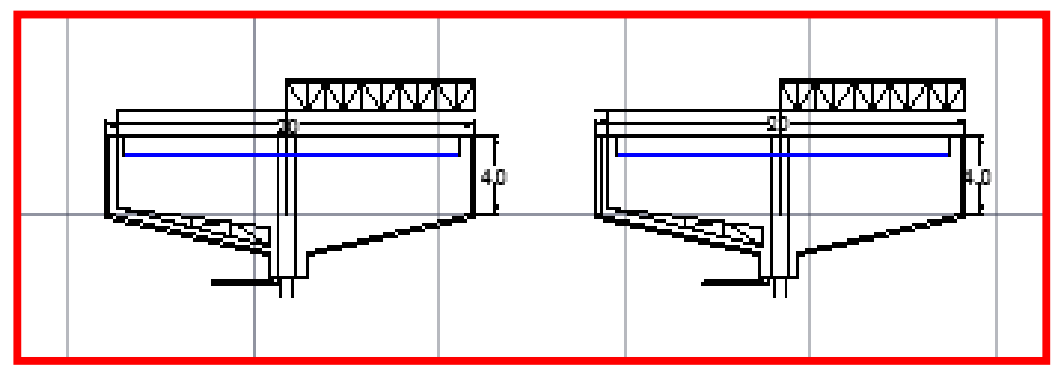

Figure 10. Side view of the clarification

$\mathrm{V}_{\mathrm{c}}=\left[\frac{8 \beta \mathrm{gd}\left(\rho_{\mathrm{s}-} \rho_{\mathrm{w}}\right)}{\mathrm{f}}\right]^{1 / 2}$

where $\mathrm{Vc}$ refers to the scouring velocity $(\mathrm{mm} / \mathrm{s})$, $\mathrm{g}$ is the acceleration due to gravity $\left(9.81 \mathrm{~m} / \mathrm{s}^{2}\right), \mathrm{f}$ is the Darcy Weisbach factor ranging from 0.02 to $0.03, \beta$ is the constant $(0.05)$, and $\mathrm{d}$ is the smallest particle $(0.02 \mathrm{~mm})$. 
$\mathrm{V}_{\mathrm{c}}=\left[\frac{8 \times 0.05 \times 9.81 \mathrm{~m} / \mathrm{s}^{2} \times 0.02\left(2600 \mathrm{~kg} / \mathrm{m}^{3}-1000 \mathrm{~kg} / \mathrm{m}^{3}\right)}{0.03}\right]^{\frac{1}{2}}$

$\mathrm{V}_{\mathrm{c}}=\frac{64.7 \mathrm{~mm}}{\mathrm{~s}}=\frac{6.47 \mathrm{~cm}}{\mathrm{~s}}$

$\mathrm{Vs}=3.56 \times 10-3 \mathrm{~cm} / \mathrm{s}<(\mathrm{Vc}=6.47 \mathrm{~cm} / \mathrm{s})$, ok

$\mathrm{Vs}=3.56 \times 10-5 \mathrm{~cm} / \mathrm{s}$

\section{Filtration}

Filtration aims to remove the suspended solids that are not removed in the sedimentation unit or when the removal of these particles take a long time outside the basin [2,20] Figure 11:

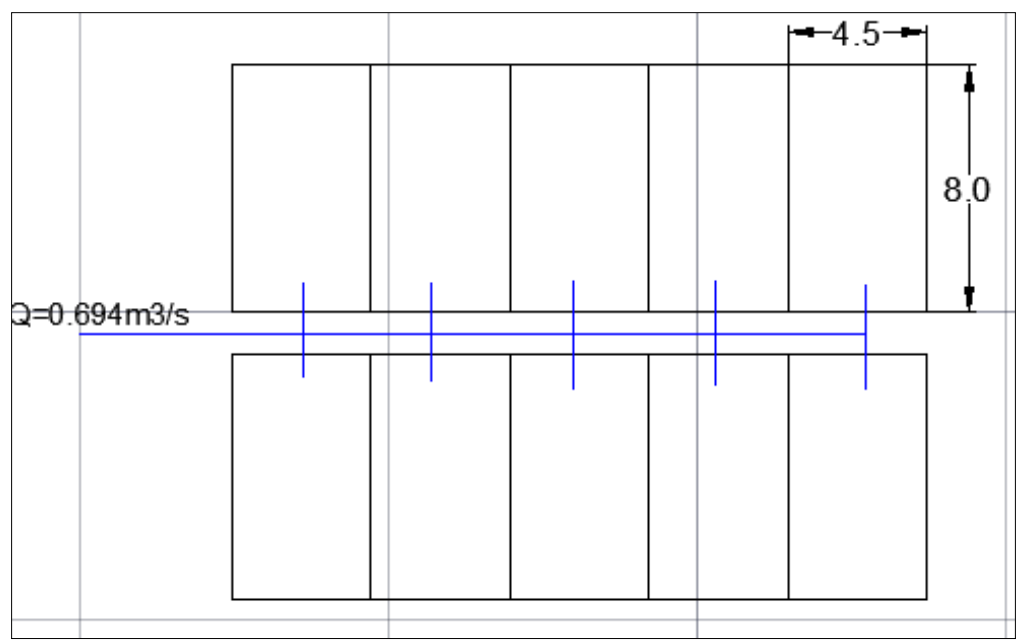

Figure 11. Plan of filtration units

To design a rapid sand filtration tank:

Q avg. $=0.694 \mathrm{~m}^{3} / \mathrm{s}=2,498.4 \mathrm{~m}^{3} / \mathrm{h}$

Using the flow of the filter: Q filter $=7 \mathrm{~m}^{3} / \mathrm{h} / \mathrm{m}^{2},[9,21]$

Area of the filter bed $A=\frac{2498.4}{7}=356.9 \mathrm{~m}^{2}$, say $357 \mathrm{~m}^{2}$

A total of 10 filter units were used, and the area of one filter unit is obtained by $A=357 / 10=35.7 \mathrm{~m}^{2}$

The width of $4.5 \mathrm{~m}$ of one filter unit was used.

Therefore, to find length $=35.7 / 4.5=7.93 \mathrm{~m}$ (say $8 \mathrm{~m}$ length and 4.5 wide, $\mathrm{A}=36 \mathrm{~m}^{2}$ )

Checking filtration rate:

Total Area $=4.5 \mathrm{~m} \times 8 \mathrm{~m} \times 10$ Nos. $=360 \mathrm{~m}^{2}$.

Filtration rate $=\frac{2498.4 \mathrm{~m} 3 / \mathrm{h}}{360 \mathrm{~m} 2}=\frac{6.94 \mathrm{~m}}{\mathrm{~h}}$, (between $\frac{5 \mathrm{~m}}{\mathrm{~h}}$ and $\left.\frac{7 \mathrm{~m}}{\mathrm{~h}}\right)$, ok

To design laterals and manifold:

Using the size of the openings at 6 or $12 \mathrm{~mm}$ [13]

Total area of perforations

$\frac{\text { Area of filter tank }}{\text { Ans }}=0.3 \%$

$\frac{\text { Total area of perforations }}{\text { Total araes of laterals }}=0.5$, for perforations with $12 \mathrm{~mm}$ diameter:

Total araes of laterals
For perforation with $\mathrm{d}$ of $12 \mathrm{~mm}$

$\mathrm{A}=\frac{\pi}{4} \mathrm{~d}^{2}=\frac{\pi}{4}(12)^{2}=113.1 \mathrm{~mm}^{2}=0.0001131 \mathrm{~m}^{2}$

Total area of perforations $=0.3 \% \times 36 \mathrm{~m}^{2}=0.108 \mathrm{~m}^{2}$

Total area of laterals $=2 \times 0.108 \mathrm{~m}^{2}=0.216 \mathrm{~m}^{2}$

Spacing between laterals $=20 \mathrm{~cm}$

To find the number of the lateral $=\frac{\text { length of one filter unit }}{\text { space between laterals }}=\frac{800 \mathrm{~cm}}{20 \mathrm{~cm}}=40$ laterals

Total number of the laterals per filter unit $=2 \times 40=80$ Nos.

Area per lateral $=0.216 \mathrm{~m}^{2} / 80$ No. $=0.0027 \mathrm{~m}^{2}$

$0.0027=\frac{\pi}{4} \mathrm{~d}^{2}$

$\mathrm{d}$ lateral $=0.0586 \mathrm{~m}$, say $5 \mathrm{~cm}$

No. of perforations $=0.108 \mathrm{~m}^{2} / 0.0001131 \mathrm{~m}^{2}=954.90$ Nos.; Use 960 Nos.

No. of perforations per lateral $=960$ Nos. $/ 80$ Nos. $=12$ Nos. per lateral

The total area of the manifold $=2 \times$ Area of the lateral

$$
\begin{aligned}
& =2 \times 0.216 \mathrm{~m}^{2} \\
& =0.432 \mathrm{~m}^{2}
\end{aligned}
$$


$0.432=\frac{\pi}{4} \mathrm{~d}^{2}$

$\mathrm{d}$ manifold $=0.742 \mathrm{~m}$, say $75 \mathrm{~cm}$

Total length of the lateral $=450-(2 \times 17+5+2 \times 3.5)=404 \mathrm{~cm}$

Length of each lateral $=404 / 4=101 \mathrm{~cm}$

The details of one filter bed unit are illustrated in Figure 12:

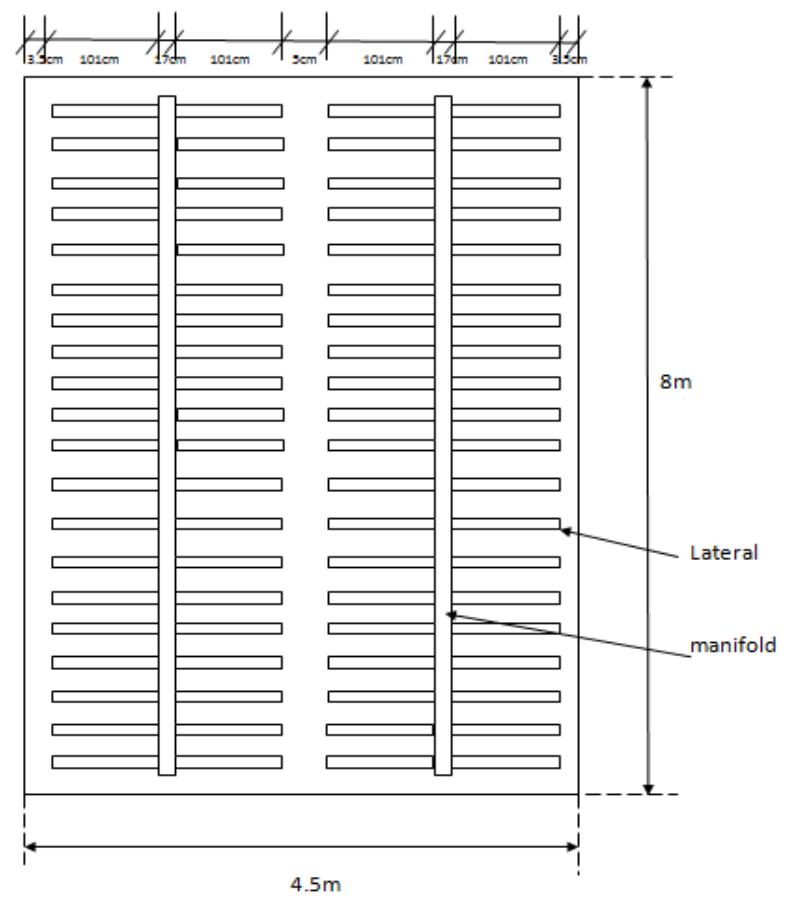

Figure 12. Detail of one filter unit

In this work, the adequate size and uniformity coefficient of the filter media was regarded as 0.5 and 1.6 , respectively [9,21] The filter media depth of $50 \mathrm{~cm}$ was proposed.

The different supporting layers with 20 and $30 \mathrm{~cm}$ were recommended for this filter[13]

The head of water above the filter media is $2 \mathrm{~m}$.

Air and water were proposed for the backwashing process for $15 \mathrm{~min}$. Total backwashing time is $30 \mathrm{~min}$.

The filter run time was assumed to be $24 \mathrm{~h}$.

The section of the filter media is shown in Figure 13:

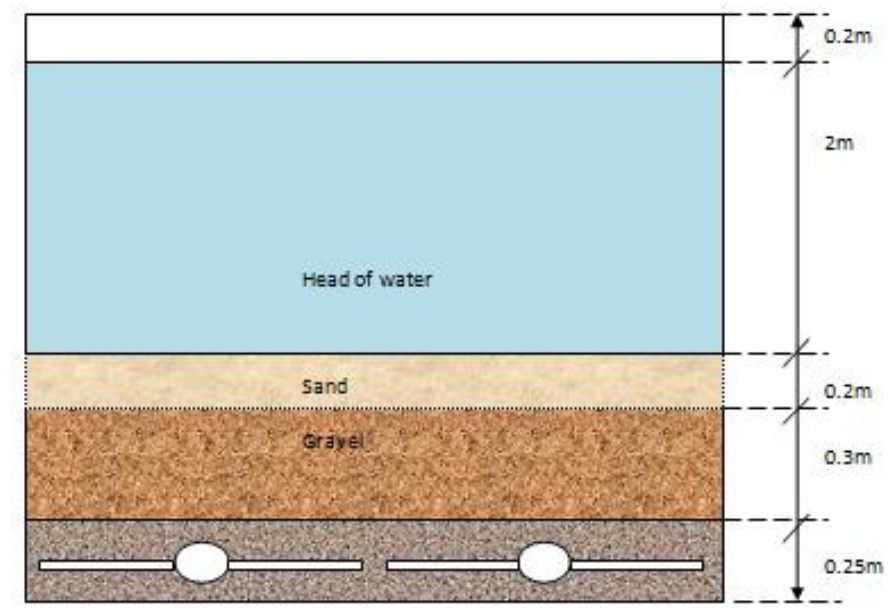

Figure13. The section of the filter media.

\section{Backwashing}

The amount of backwashing water should be less than or equal to the 5\% rate of the filtered water [13].

Rate of wash water $=\left(7 \mathrm{~m}^{3} / \mathrm{h} / \mathrm{m}^{2}\right) /(10$ filter $)=0.7 \mathrm{~m}^{3} / \mathrm{h} / \mathrm{m}^{2}$

$\mathrm{Q}$ backwash $=0.5 \times 7 \mathrm{~m}^{3} / \mathrm{h} / \mathrm{m}^{2}=3.5 \mathrm{~m}^{3} / \mathrm{h} / \mathrm{m}^{2}$

Two filter beds were washed at the same time. 
Wash area $=2 \times 36 \mathrm{~m}^{2}=72 \mathrm{~m}^{2}$

Amount of water needed for washing $=72 \mathrm{~m}^{2} \times 7 \mathrm{~m}^{3} / \mathrm{h} / \mathrm{m}^{2}=504 \mathrm{~m}^{3} / \mathrm{h}$

Head of wash water $=10 \mathrm{~m}$

Frictional resistance $=4 \mathrm{~m} \quad[13]$

Total head required $=10+4=14 \mathrm{~m}$

We used two pumps in parallel, and each pump has a capacity of $700 \mathrm{~m}^{3} / \mathrm{h}$ with a head of $14 \mathrm{~m}$.

\section{Trough Design:}

To determine the flow through the trough $=\left(0.694 \mathrm{~m}^{3} / \mathrm{s}\right) /(2$ trough $\times 10$ filters $)$

$\mathrm{Q}=0.0347 \mathrm{~m}^{3} / \mathrm{s}$

$\mathrm{Q}=2.49 \mathrm{bh}^{\frac{3}{2}}$

$0.0347 \mathrm{~m}^{3} / \mathrm{s}=2.49 \times \mathrm{b} \times(0.15)^{3 / 2}$

$\mathrm{b}=0.24 \mathrm{~m}$

Total depth $=15 \mathrm{~cm}+5 \mathrm{~cm}($ freeboard $)=20 \mathrm{~cm}$

The details of the trough are shown in Figure 14

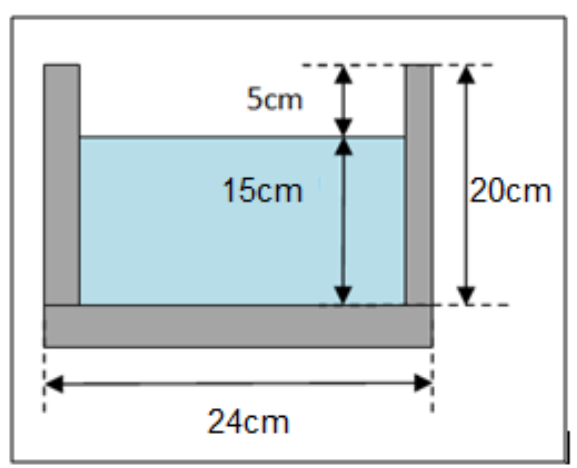

Figure14. Detail of the trough

\section{Adsorption}

Activated carbon is used to remove colors and tastes in water, resulting in the presence of dissolved gases. It is also porous and has many carbon atoms with free valencies. In addition, it is available in granular or powder form. Granular activated carbon has a surface area of $500-1400 \mathrm{~m}^{2} / \mathrm{g}[20,22]$

Activated carbon can be applied to treat water in two ways:

As powder feed (during adding alum to mixing basin or after coagulation)

As filter media (instead of sand filter bed [13, 19].

Adsorption isotherm is a mathematical model that describes the distribution of adsorbate species among liquid and adsorbent based on the assumptions of heterogeneity/homogeneity of adsorbents.

Adsorption data are described by Langmuir or Freundlich adsorption isotherms.

\section{Langmuir isotherm}

This model is based on the assumption that maximum adsorption occurs when a saturated monolayer of solute molecules is present on the adsorbent surface. The energy of adsorption is constant, and adsorbate molecules do not migrate on the surface plane [20,22-23]. The Langmuir isotherm equation is stated as follows:

$\mathrm{q}_{\mathrm{e}}=\frac{\mathrm{q}_{\mathrm{mK}} \mathrm{C}_{\mathrm{e}}}{1+\mathrm{K}_{\mathrm{L}} \mathrm{C}_{\mathrm{e}}}$

The constants of the Langmuir isotherm can be determined by plotting (1/qe) versus $(1 / \mathrm{Ce})$, and the above equation is rewritten as follows:

$\frac{1}{\mathrm{q}_{\mathrm{e}}}=\frac{1}{\mathrm{q}_{\mathrm{m}}}+\frac{1}{\mathrm{q}_{\mathrm{m}} \mathrm{K}_{\mathrm{L}}} \frac{1}{\mathrm{C}_{\mathrm{e}}}$

Where

qe refers to weight of adsorbate $(\mathrm{g})$

$\mathrm{qm}$ is the Langmuir constant $(\mathrm{mg} / \mathrm{g})$

$\mathrm{KL}$ is the Langmuir constant $(\mathrm{L} / \mathrm{mg})$

$\mathrm{Ce}$ is the equilibrium concentration of adsorbate $(\mathrm{mg} / \mathrm{L})$.

\section{Freundlich isotherm}

This model is an empirical relationship describing the adsorption of solutes from a liquid to a solid surface and assumes that different sites with several adsorption energies are involved [20,22-23]. The equation is as follows:

$\mathrm{q}_{\mathrm{e}}=\mathrm{K}_{\mathrm{f}} \mathrm{C}_{\mathrm{e}}^{1 / \mathrm{n}}$

The equation in the form of logarithm becomes: 
$\log =\log \mathrm{K}_{\mathrm{f}+} \frac{1}{2} \log \mathrm{C}_{\mathrm{e}}$

where (Kf) and (n) are Freundlich constants, the characteristics of the system. The settled water in the laboratory should be subjected to kinetic analysis to determine the optimum dosage of the adsorbent.

\section{Disinfection}

When the filtered water comes out from the filter unit, bacteria and other microorganisms, which may be pathogenic, may exist.

Thus, disinfection is necessary to eliminate bacteria and other microorganisms and consequently prevent waterborne diseases.

Disinfection involves a number of methods. The use of chlorine has become particularly common in disinfecting water. It is

inexpensive, reliable, and relatively safe to handle [19].

Water demand $=60,000 \mathrm{~m}^{3} /$ day

Required chlorine and residual chlorine are 0.36 and $0.2 \mathrm{mg} / \mathrm{L}$, respectively [19].

Chlorine demand $=0.36 \mathrm{mg} / \mathrm{L}-0.2 \mathrm{mg} / \mathrm{L}=0.16 \mathrm{mg} / \mathrm{L}$

Consumed chlorine $=0.36 \mathrm{mg} / \mathrm{L} \times(1 / 106) \times 60,000 \times 1000=21.6 \mathrm{~kg} / \mathrm{day}$

The time required to complete the disinfection performed in a storage tank is $0.5 \mathrm{~h} \mathrm{[13].}$

$\mathrm{Q}=$ Volume $/$ time

Volume $=\mathrm{Q} \times$ time

Volume $=60,000 \mathrm{~m}^{3} /$ day $\times(1 / 24) \times 0.5 \mathrm{~h}=1,250 \mathrm{~m}^{3}$

Using effective depth of $4 \mathrm{~m}$ and length $(\mathrm{L})=2 \times$ width $(\mathrm{W})$

$\mathrm{A}=1,250 \mathrm{~m}^{3} / 4 \mathrm{~m}=312.5 \mathrm{~m}^{2}$

$\mathrm{L} \times \mathrm{W}=312.5 \mathrm{~m}^{2}$

$2 \mathrm{~W} \times \mathrm{W}=312.5 \mathrm{~m}^{2}$

$\mathrm{W}^{2}=156.25 \mathrm{~m}^{2}$

$\mathrm{W}=12.5 \mathrm{~m}$ and $\mathrm{L}=2 \times 12.5=25 \mathrm{~m}$

Velocity $=$ distance $/$ time

Velocity $=25 \mathrm{~m} / 0.5 \mathrm{~h}=50 \mathrm{~m} / \mathrm{h}=0.0139 \mathrm{~m} / \mathrm{s}$

\section{Storage and pumping}

When the final stages of the treatment process are completed, water can be distributed by high lift pumps to consumers or stored in storage tanks. Thereafter, it can be used as drinking water based on the required household demand.

The details of the storage tank and the pumping are shown in Figures 15 and 16:

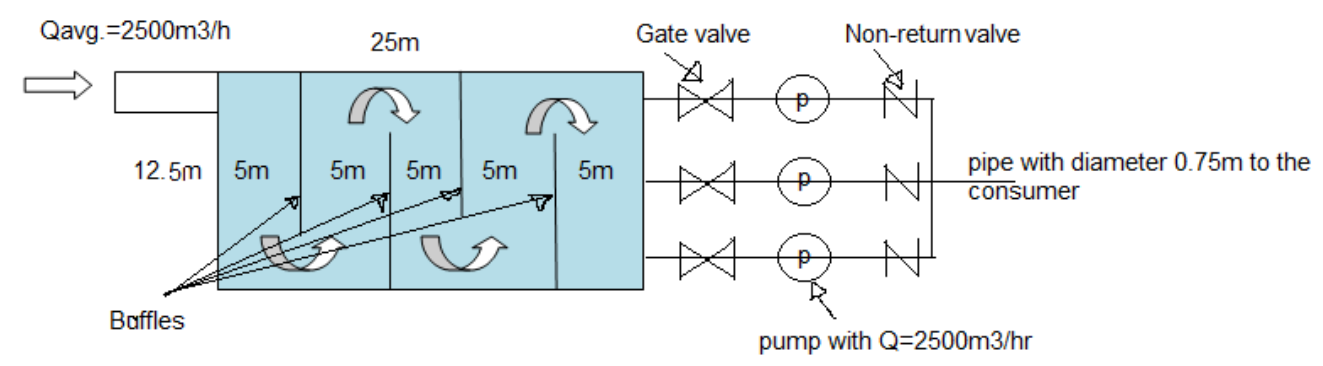

Figure 15. Plan of the disinfection and storage tanks

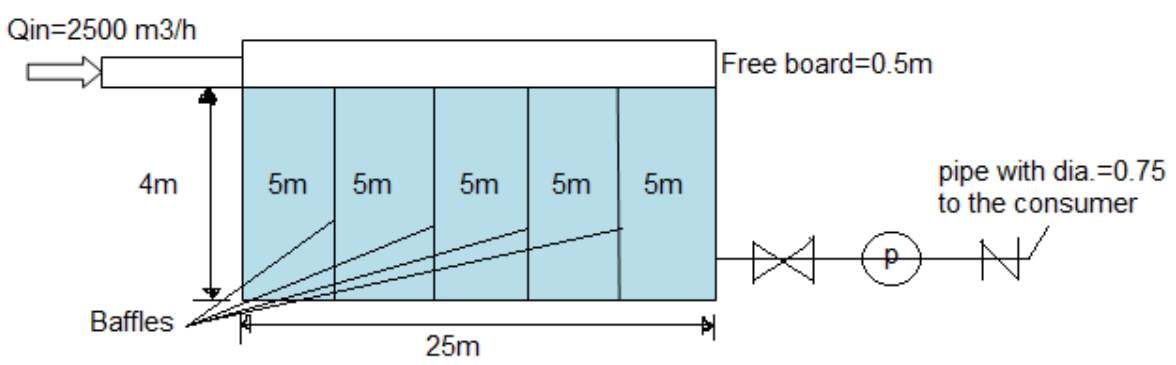

Figure 16. Section of the disinfection and storage tanks.

Q avg. $=60,000 \mathrm{~m}^{3} /$ day $=2,500 \mathrm{~m}^{3} / \mathrm{h}=0.6944 \mathrm{~m}^{3} / \mathrm{s}$

Using $\mathrm{v}=1.5 \mathrm{~m} / \mathrm{s}$, (Metcalf and eddy, 2014)

$\mathrm{A}=\frac{0.6944}{\frac{\pi}{4} \times\left(0.75^{2}\right)}=\frac{1.57 \mathrm{~m}}{\mathrm{~s}}<2 \mathrm{ok}$ 
Two pumps are used; the first pump is working, and the second one is on standby. The third pump is used during maximum demand.

\section{Outline of WTP design}

The final output of the design steps of the WTP is summarized in Table 3.

Table 3. Summary of the WTP design outline

\begin{tabular}{|c|c|c|c|c|c|}
\hline No. & Unit description & $\begin{array}{c}\text { No. of } \\
\text { unit }\end{array}$ & Shape of unit & Dimensions of units & Notes \\
\hline 1 & Intake & 4 & circular & $\begin{array}{c}\text { Diameter }=5.15 \mathrm{~m} \\
\text { Depth }=10 \mathrm{~m}\end{array}$ & $\begin{array}{c}\text { Diameter of suction pipe }=0.4 \mathrm{~m} \\
\text { Diameter of raw water gravity pipe } \\
=0.5 \mathrm{~m}\end{array}$ \\
\hline 2 & Coagulation & 2 & circular & $\begin{array}{l}\text { Diameter }=3 \mathrm{~m} \\
\text { Depth }=3 \mathrm{~m}\end{array}$ & $\begin{array}{c}\mathrm{G}=300 \mathrm{~s}^{-1} \\
\mathrm{P}=21 \mathrm{KW} \\
\mathrm{t}=1 \mathrm{~min}\end{array}$ \\
\hline 3 & Flocculation & 6 & Rectangle & $\begin{array}{c}\text { Width }=4.17 \mathrm{~m} \\
\text { Length }=3 * 4.17=12.51 \mathrm{~m} \\
\text { Depth }=4 \mathrm{~m}\end{array}$ & $\begin{array}{c}\mathrm{G}=20,40 \text {, and } 60 \mathrm{~s}^{-1} \\
\mathrm{P}=84,336 . .02 \text {, and } 756.04 \text { watt } \\
\mathrm{t}=30 \mathrm{~min}\end{array}$ \\
\hline 4 & Clarification & 4 & circular & $\begin{array}{c}\text { Diameter }=28 \mathrm{~m} \\
\text { Depth }=4 \mathrm{~m}\end{array}$ & $\begin{array}{c}\mathrm{V}_{\mathrm{s}}=0.3594 \mathrm{~mm} / \mathrm{s} \\
\mathrm{V}_{\mathrm{c}}=64.7 \mathrm{~mm} / \mathrm{s} \\
\mathrm{d}_{\mathrm{p}}=0.02 \mathrm{~mm}\end{array}$ \\
\hline 5 & Filtration & 10 & Rectangle & $\begin{array}{l}\text { Width }=4.5 \mathrm{~m} \\
\text { Length }=8 \mathrm{~m} \\
\text { Depth }=3 \mathrm{~m}\end{array}$ & $\begin{array}{c}\text { Filtration }=6.94 \mathrm{~m} / \mathrm{hr} \\
\text { Rate }= \\
\text { Backwashing }=124.92 \mathrm{~m} / \mathrm{hr}\end{array}$ \\
\hline 6 & Disinfection & 1 & Rectangle & $\begin{array}{c}\text { Width }=12.5 \mathrm{~m} \\
\text { Length }=25 \mathrm{~m} \\
\text { Depth }=4 \mathrm{~m}\end{array}$ & $\begin{array}{c}\text { Time }=30 \mathrm{~min} \\
\text { Consumed chlorine }=21.6 \mathrm{~kg} / \mathrm{d}\end{array}$ \\
\hline 7 & $\begin{array}{l}\text { Storage } \\
\text { \&pumping }\end{array}$ & 3pumps & & $\begin{array}{l}\mathrm{Q}=2500 \mathrm{~m}^{3} / \mathrm{hr} \\
\mathrm{V}=1.57 \mathrm{~m} / \mathrm{s} \\
\mathrm{D}_{\text {pipe }}=0.75 \mathrm{~m}\end{array}$ & Dosage \\
\hline
\end{tabular}

\section{The efficiency of the WTP}

A total of three WTPs were constructed on Greater Zab River. Built-in 1982, Erbil ETP is located on the right side of ErbilAinkawa main road [24]. To appraise the performance of the WTP units, we can use the following equation:

Removal Efficiency $(\%)=\frac{\mathrm{C}_{\mathrm{o}}-\mathrm{C}_{\mathrm{f}}}{\mathrm{C}_{\mathrm{o}}} \times 100 \%$

where $\mathrm{C}_{\mathrm{o}}$ is the initial concentration, and $\mathrm{C}_{\mathrm{f}}$ is the final concentration.

Based on the collected data, the authors obtained the average removal efficiencies of turbidity in flash mixing, sedimentation tank, filtration unit, and after disinfection in the final storage tank in were $15.21 \%, 59.8 \%, 72.72 \%$, and $85.21 \%$, respectively [24]. The average turbidity of raw water was 12.62 NTU, whereas the average turbidity of the treated Greater-Zab water in Erbil WTP was 1.86 NTU, which is acceptable for drinking water [24]. Greater values of 4 NTU to 5 NTU and 2.31 NTU to 5.44 NTU for treated water were reported in the literature [25-26]. Issa [27] reported that the turbidity value for the treated water for Khanaqin City WTP was 5.5 NTU which greater than the drinking water standards [14]. The overall efficiency for the Khanaqin WTP was 97.88 $\%$ [27]. Removal efficiencies for sedimentation tank and filter unit for Al-wahdaa Project Drinking WTP were 46\% and 75\%, respectively [28]. The obtained results by Mohammed and Shakir [28] were very close to the achieved data by Goran [24]. Age of the WTP, maintenance, economical and political situations, technical problems had a great impact on the removal efficiency of the WTP units.

\section{CONCLUSIONS}

A typical step-by-step design for WTP units was presented. Procedures, detailed calculations, and drawings were illustrated. The average discharge of $60,000 \mathrm{~m}^{3} /$ day and a population of 200,000 were used in the design of WTP. The outputs of the calculations and the details of the WTP units were tabulated. The quality and quantity of the surface water source affected the WTP design. Surface water resource such as Greater-Zab River needs treatment due to high concentration of some pollutants. The parameters of each unit and the whole WTP by using the pilot scale should be optimized. Populations should be predicted using various methods to use WTP services without any problems. Based on the obtained calculations and details it is concluded that, the study can be used as a base reference for the future works and to design of any WTP units. A number of factors such as age of WTP, maintenance, economical and political situations, technical problems, and water demand had a great impact on the removal efficiency of the WTP units.

\section{REFERENCES}

1. WarrenViessman, J.R., \& Hammer, M. J. (1985). Water Supply and Pollution Control, $4^{\text {th }}$ edition. Happer \&Row, Publishers, NewYork. 
2. Hammer, M. J. \& Hammer, Jr. M. J. (1996). Water and Wastewater Technology. $3^{\text {rd }}$ edition. Prentice-Hall, Inc.

3. Singh, G. \& Singh, J. (2003). Water Supply and Sanitary engineering. $6^{\text {th }}$ edition. Lomus offset press, Delhi.

4. Brandt M.J., Johnson K.M., Elphanston A.J., \& Ratnayaka D.D. (2017). Twort's Water Supply. $7^{\text {th }}$ Edition, Published by Elsevier Ltd.

5. Huang J.Y.C., \& Garcia-Maura F. (1986). Effect of Influent Property on Filter Performance. J. of Envr. Eng.Div. 112(4).

6. Mohammed, O.I. (1989). A Comparison Between the Performance of the Conventional and the Dual-Media Filters. M.Sc. thesis, Civil Engineering Department, University of Basrah, Iraq.

7. Rashid, M. A. (1989). Treatment of Tigris river water by direct filtration. M.Sc. thesis, University of Baghdad, Iraq.

8. Al-Anbari, R.H.H. (1997). Selected Alternatives for Up-Grading Existing Water Treatment-Plants: A Qualitative and Qualitative Improvements. PhD thesis, Building and Construction Department, University of Technology, Iraq.

9. Aziz, S. Q. (2000). Treatment of Greater-Zab Water by Rapid Filtration. M. Sc. Thesis, Department of Civil Engineering, College of Engineering, Salahaddin University-Erbil, Erbil, Iraq.

10. Aziz, S.Q. (2009). Determination of Floc Volume Concentration in Filter Beds by Using New Methods. Thirteenth International Water Technology Conference, IWTC 13, Hurghada, Egypt.

11. Directorate of water in Erbil City (DOW, 2017). Ministry of Municipality and Tourism. KRG-Iraq.

12. Hanna, N. S., \& Shekha, Y. A. (2015). Using aquatic insects in water quality assessment of some branches of Greater Zab River within Erbil City. Iraqi Kurdistan Region, American International Journal of Research in Formal, Applied \& Natural Sciences, AIJRFANS 15-316: 18-22.

13. McGhee, T.J. (1991). Water Supply and Sewerage. $6^{\text {th }}$ edition. International Student Edition.

14. World Health Organization (1997). Guidelines for Drinking Water Quality. $2^{\text {nd }}$ Edition. Volume 2. Amman, Jordan.

15. Aziz, S.Q., \& Fakhrey, E. S. (2016). The Effect of Kawergosk Oil Refinery Wastewater on Surrounding Water Resources. Zanco-Journal of Pure and Applied Sciences, Salahaddin University-Erbil, 28 (2): 656-667.

16. Al-Layla M. A., Shamim A., \& Joe Milddlebrooks, E. (1977). Water Supply Engineering Design. Ann Arbor Science Publishers, Inc. ISBN 0-250-40147-9.

17. Davis, M. L. (2010). Water and Wastewater Engineering-Design Principles and Practice. The McGraw Hill Companies.

18. Patil, G., Sambrekar, B., Dukare, G., Kansagara, P., \& Hingmire, A. (2018).Study of Water Treatment Plant Jalgaon. International Journal of Innovative Research in Science, Engineering and Technology 7(4): 4038-4044.

19. Punmia, B.C., Jain A. K., \& Jain, A. K. (1995). Environmental Engineering-Water Supply Engineering. LAXMI Publication (P) LTD, New Delhi 110002..

20. Metcalf \& Eddy (2014). Wastewater Engineering: Treatment and Reuse, 5th edition, Inc., Mc Graw-Hill, New York.

21. Amin, K.A., \& Aziz, S.Q. (2002). Pressure Distribution in Filter Media in Conventional Filters. Journal of Duhok UniversityScientific and Academic, 5 (2): 56-59.

22. Fakhrey, E.S. (2016). Impact of Resulted Wastewater from Kourkosk Oil Refinery (Erbil-Iraq) on Water Resources and Improvement of the Treatment Process by Adsorption Added to Biological Techniques. M.Sc. Thesis, Department of Dams and Water Resources Engineering, College of Engineering, Salahaddin University-Erbil, Iraq.

23. Amin, A. A., Smail, H. A., \& Amin, H. I. M. (2018). Isotherm Studies of Adsorption of Cadmium (II) ion from Aqueous Solution onto Zeolite: Effects of Time, Temperature and pH. ZANCO Journal of Pure and Applied Sciences, 30 (1): $23-33$.

24. Goran, S. M. A. (2009). Evaluation of Ifraz Water Treatment Plants In Erbil City-Iraq. J. Edu. \& Sci., 23(4): 58-79.

25. Jahanshahi, M., \& Taghizadeh, M.M. (2018). Pre-sedimentation tank effects on water treatment unit operation. Environmental quality/Qualité de l'Environment / Qualità ambientale, 28: 35-42.

26. Hassan, F. M, \& Mahmood, A. R. (2018). Evaluate the Efficiency of Drinking Water Treatment Plants in Baghdad City-Iraq. Journal of Applied \& Environmental Microbiology 6(1): 1-9.

27. Issa, H. M. (2018). Evaluation of Water Quality and Performance for a Water Treatment Plant: Khanaqin City as a Case Study. Journal of Garmian University: 802-811. doi.org/10.24271/garmian.64.

28. Mohammed, A. A., \& Shakir, A. A. (2012). Evaluation the Performance of Al-wahdaa Project Drinking water treatment Plant: A case study in Iraq. International Journal of Advances in Applied Sciences (IJAAS). 1(3): 130-138. 